Al-Kharaj: Jurnal Ekonomi, Kenangan \& Bisnis Syariah

Volume 4 No 4 (2022) 1166-1185 P-ISSN 2656-2871 E-ISSN 2656-4351

DOI: 10.47467/alkharaj.v4i4.888

\title{
Pengaruh Return on Asset, Growth, dan Free Cash Flow terhadap Dividend Payout Ratio (DPR) dengan Corporate Governance sebagai Variabel Intervening
}

\author{
Asmarysa Pangestytyca ${ }^{1}$, Sri Hermuningsih ${ }^{2}$, Ratih Kusumawardhani ${ }^{3}$ \\ Fakultas Ekonomi, Universitas Sarjanawiyata Tamansiswa Yogyakarta \\ apangestytyca@gmail.com, hermun_feust@yahoo.co.id
}

\begin{abstract}
This study aims to determine the effect of the Return On Asset, Growth, and Free Cash Flow ratio on the Dividend Payout Ratio (DPR) in manufacturing companies in the consumer goods industry sector listed on the Indonesia Stock Exchange (IDX) in 2016-2020. The data collection technique used purposive sampling method. This research is a type of quantitative research and uses secondary data. So that a sample of 53 data was obtained from 17 manufacturing companies in the consumer goods industry sector listed on the Indonesia Stock Exchange (IDX) in 2016-2020. The data analysis method uses multiple linear regression analysis using SPSS version 23. The results of the study show that Return On Assets (ROA) has a positive and significant effect on the Dividend Payout Ratio (DPR). Growth and Free Cash Flow (FCF) partially have a negative and significant effect on the Dividend Payout Ratio (DPR). Corporate Governance (CG) has no significant effect on the Dividend Payout Ratio (DPR). The effect of ROA on the Dividend Payout Ratio (DPR) through Corporate Governance (CG) as an intervening variable is rejected. The effect of Growth and Free Cash Flow (FCF) partially on the Dividend Payout Ratio (DPR) through Corporate Governance (CG) as an intervening variable is accepted.
\end{abstract}

Keywords: Return On Asset; Growth; Free Cash Flow; Dividend Payout Ratio; Corporate Governance

\section{ABSTRAK}

Penelitian ini bertujuan untuk mengetahui adanya pengaruh rasio Return On Asset, Growth, dan Free Cash Flow terhadap Dividend Payout Ratio (DPR) pada perusahaan manufakur sektor consumer goods industry yang terdaftar di Bursa Efek Indonesia (BEI) pada tahun 20162020. Teknik pengambilan data menggunakan metode purposive sampling. Penelitian ini merupakan jenis penelitian kuantitatif dan menggunakan data sekunder. Sehingga diperoleh data sampel sebanyak 53 data dari 17 perusahaan manufakur sektor consumer goods industry yang terdaftar di Bursa Efek Indonesia (BEI) pada tahun 2016-2020. Metode analisis data menggunakan analisis regresi linear berganda yang menggunakan SPSS versi 23. Hasil dari penelitian menunjukan bahwa Return On Assets (ROA) berpengaruh positif dan signifikan terhadap Dividend Payout Ratio (DPR). Growth dan Free Cash Flow(FCF) secara parsial berpengaruh negatif dan signifikan terhadap Dividend Payout Ratio (DPR). Corporate Governance (CG) tidak berpengaruh signifikan terhadap Dividend Payout Ratio (DPR). Pengaruh ROA terhadap Dividend Payout Ratio (DPR) melalui Corporate Governance (CG) sebagai variabel intervening ditolak. Pengaruh Growth dan Free Cash Flow (FCF) secara parsial terhadap Dividend Payout Ratio (DPR) melalui Corporate Governance sebagai variabel intervening diterima. 


\section{A1-Kharaj: Jurnal Ékonomi, Kenangan \& Bisnis Syariah \\ Volume 4 No 4 (2022) 1166-1185 P-ISSN 2656-2871 E-ISSN 2656-4351 DOI: $10.47467 /$ alkharaj.v4i4.888}

Kata kunci: Return On Asset; Growth; Free Cash Flow; Dividend Payout Ratio; Corporate Governance

\section{PENDAHULUAN}

Suatu perusahaan pasti mempunyai tujuan yang ingin dicapai, salah satunya adalah meningkatkan kesejahteraan dan kekayaan para investor dengan meningkatkan nilai perusahaan. Nilai perusahaan akan meningkat apabila perusahaan mampu beroperasi dan mendapat keuntungan maksimal yang ditargetkan. Dari keuntungan yang diperoleh, perusahaan dapat membagikan dividen kepada para pemegang saham, dapat meningkatkan pertumbuhan perusahaan, dan menjamin kelangsungan hidup perusahaan (Adnan et al., 2014). Menurut Khan et al. (2017), pembayaran dividen adalah bagian dari laba bersih/laba bersih yang dibayarkan asosiasi atau perusahaan kepada pemilik sahamnya dalam bentuk dividen. Cahyadi et al. (2018) beragumen bahwa nilai DPR menggambarkan seberapa besar return yang akan diterima investor ketika investor melakukan investasi saham. Meskipun demikian, pembagian return dalam bentuk dividen membutuhkan pertimbangan khusus.

Profitabilitas mutlak diperlukan oleh perusahaan apabila akan membayar dividen karena profitabilitas diartikan sebagai kemampuan perusahaan untuk menghasilkan laba atau profit dalam upaya meningkatkan nilai pemegang saham (Mahaputra \& Wirawati, 2014). Return on assets (ROA) adalah salah satu ukuran profitabilitas perusahaan dalam menghasilkan keuntungan dengan memanfaatkan aset yang digunakan untuk operasi. Posisi dari nilai ROA yang tinggi menunjukkan bahwa perusahaan berkemampuan dalam menghasilkan keuntungan yang berbanding dengan aset yang relatif tinggi (Atmoko et al., 2018). Penelitian Kusuma et al. (2018), (Hanif \& Bustaman, 2017)) serta (Sumampow \& Murni, 2016) menyatakan bahwa ROA berpengaruh positif terhadap dividend payout ratio. Sebaliknya Demirgüneş \& Üniversitesi (2015) dan Atmoko et al. (2018) menyatakan bahwa ROA berpengaruh negatif terhadap DPR. Adapun hasil penelitian dari Adnan et al. (2014), Laim et al. (2015), dan Parera (2016) yang menyatakan bahwa ROA tidak berpengaruh terhadap DPR.

Ada faktor lain yang mempengaruhi DPR adalah pertumbuhan perusahaan atau growth. Growth menunjukkan pertumbuhan aset dimana aset merupakan aktiva yang digunakan untuk aktivitas operasional perusahaan (Laim et al., 2015). Pertumbuhan perusahaan dapat mencerminkan bahwa suatu perusahaan akan berkembang atau tidak. Pertumbuhan perusahaan adalah suatu rasio yang memperlihatkan kemampuan perusahaan untuk menjaga posisi ekonominya ditengah pertumbuhan perekonomian dan sektor usahanya (Suwardika \& Mustanda, 2017). Menurut Brigham (2011, dalam Novita Sari \& Sudjarni, 2015) pertumbuhan perusahaan akan mempengaruhi kebijakan 


\section{A1-Kharaj: Jurnal Ékonomi, Kenangan \& Bisnis Syariah Volume 4 No 4 (2022) 1166-1185 P-ISSN 2656-2871 E-ISSN 2656-4351 DOI: 10.47467/alkharaj.v4i4.888}

dividen dimana dengan tingkat pertumbuhan yang baik perusahaan tentunya akan megalokasikan dana yang didapat perusahaan untuk berinvestasi sehingga akan mengurangi pembagian dividen kepada para pemegang saham. Penelitian Sulistiyo et al. (2016) serta Putri \& Rokhim (2016) menyatakan bahwa growth mempunyai pengaruh positif terhadap DPR. Berbeda dengan penelitian Adnan et al. (2014), Laim et al. (2015), Hossain et al. (2014), dan Parsian \& Koloukhi (2014) menyatakan bahwa growth tidak berpengaruh terhadap DPR.

Faktor lain yang juga dapat mempengaruhi dividend payout ratio yaitu arus kas bebas atau free cash flow (FCF). Free cash flow secara sederhana dapat diterjemahkan sebagai kas yang menganggur, yaitu sisa kas setelah digunakan untuk berbagai keperluan proyek yang telah direncanakan perusahaan, seperti melunasi utang, membayar dividen, melakukan investasi, dan lain-lain (Dwi \& Ambarwati, 2014). Semakin besar free cash flow yang tersedia dalam suatu perusahaan, maka dapat dikatakan bahwa semakin sehat perusahaan tersebut karena memiliki kas yang tersedia untuk pembayaran hutang dan dividen (Prasetio \& Suryono, 2016). Penelitian Labhane (2015), Khan et al. (2017), Adnan et al. (2014), serta Prasetio \& Suryono (2016) menyatakan bahwa free cash flow mempunyai pengaruh positif terhadap DPR. Namun, sebaliknya penelitian Putri \& Rokhim (2016) dan Parsian \& Koloukhi (2014) menyatakan bahwa free cash flow tidak berpengaruh terhadap DPR.

Pada penelitian ini variabel intervening yaitu corporate governance (CG) diproksikan menggunakan kepemilikan manajerial. Kepemilikan manajerial merupakan saham yang dimiliki oleh dewan direksi dan dewan komisaris atau pihak manajemen lainnya. Dengan kepemilikan manajerial yang tinggi diharapkan pihak manajemen dapat memaksimalkan kepentingan pemegang saham. Dikarenakan apabila perusahaan mendapatkan laba maka pihak manajemen juga akan mendapatkan keuntungan (Bintara, 2018).

\section{Rumusan Masalah}

1. Apakah ROA berpengaruh terhadap DPR?

2. Apakah Growth berpengaruh terhadap DPR?

3. Apakah FCF berpengaruh terhadap DPR?

4. Apakah ROA berpengaruh terhadap DPR?

5. Apakah Growth berpengaruh terhadap CG?

6. Apakah FCF berpengaruh terhadap CG?

7. Apakah CG berpengaruh terhadap DPR?

\section{Tujuan Penelitian}

1. Untuk menganalisis dan mengkaji pengaruh ROA terhadap DPR.

2. Untuk menganalisis dan mengkaji pengaruh Growth terhadap DPR.

3. Untuk menganalisis dan mengkaji pengaruh FCF terhadap DPR. 


\section{Al-Kharaj: Jurual Ekonomi, Kenangan \& Bisnis Syariah}

\section{Volume 4 No 4 (2022) 1166-1185 P-ISSN 2656-2871 E-ISSN 2656-4351 DOI: 10.47467/alkharaj.v4i4.888}

4. Untuk menganalisis dan mengkaji pengaruh ROA terhadap DPR.

5. Untuk menganalisis dan mengkaji pengaruh Growth terhadap CG.

6. Untuk menganalisis dan mengkaji pengaruh FCF terhadap CG.

7. Untuk menganalisis dan mengkaji pengaruh CG terhadap DPR.

\section{METODE PENELITIAN}

\section{Sifat Penelitian}

Penelitian ini bertujuan untuk menganalisis data sampel yang telah diambil dan kemudian diramalkan dan ditarik kesimpulannya, oleh karena itu penelitian ini bersifat inferensial. Penelitian ini juga dikategorikan ke dalam penelitian kuantitatif. Penelitian dengan pendekatan kuantitatif menekankan analisis pada data numerik (angka) yang kemudian dianalisis dengan metode statistik yang sesuai. Biasanya, penelitian kuantitatif digunakan dalam penelitian inferensial untuk menguji hipotesis. Hasil uji statistik dapat menyajikan signifikansi hubungan yang dicari. (Hardani et al., 2020).

\section{Populasi}

Populasi adalah keseluruhan objek yang ditentukan oleh peneliti untuk diteliti. Populasi pada penelitian ini yaitu perusahaan manufaktur sektor consumer goods industry yang terdaftar di BEI periode 2016-2020 berjumlah 63 populasi.

\section{Sampel}

Sampel yang diambil pada penelitian ini terdiri dari 17 perusahaan manufakur pada sektor consumer goods industry yang terdaftar di Bursa Efek Indonesia (BEI) pada tahun 2016-2020. Kriteria perusahaan yang dijadikan sampel pada penelitian ini adalah sebagai berikut :

1. Perusahaan yang terdaftar di Bursa Efek Indonesia (BEI) dan mempublikasikan laporan keuangan tahunan secara berturut-turut di tahun 2016-2020.

2. Perusahaan yang membagikan dividen secara berturut-turut pada tahun 2016-2020.

3. Perusahaan yang menyediakan kelengkapan data laporan keuangan untuk menghitung variabel-variabel yang diteliti.

\section{Teknik Pengambilan Sampel}

Pada penelitian ini, peneliti dalam pengambilan sampel menggunakan metode purposive sampling. Metode purposive sampling merupakan metode pengambilan sampel yang didasarkan pada beberapa pertimbangan atau kriteria tertentu (Atmoko et al., 2018). 


\section{Al-Kharaj: Jurnal Ekonomi, Kenangan \& Bisnis Syariah \\ Volume 4 No 4 (2022) 1166-1185 P-ISSN 2656-2871 E-ISSN 2656-4351 DOI: $10.47467 /$ alkharaj.v4i4.888}

\section{Sumber dan Metode Pengambilan Data}

Penelitian ini menggunakan jenis data sekunder, berupa data laporan keuangan tahunan perusahaan sektor consumer goods industry tahun 2016-2020. Dalam penelitian ini, metode pengumpulan data yang dipakai peneliti adalah dengan metode dokumentasi dan metode studi pustaka. Metode dokumentasi yaitu mendokumentasikan data berupa laporan keuangan tahunan yang diperoleh dari situs resmi Bursa Efek Indonesia (www.idx.co.id). Sedangkan metode studi pustaka, yaitu dengan mengumpulkan informasi dari beberapa buku dan berbagai jurnal ilmiah yang berkaitan dengan masalah penelitian untuk memperkuat dukungan teori.

\section{Tempat dan Waktu Pengambilan Data}

Penelitian ini dilakukan pada Perusahaan Sektor Consumer Goods Industry yang terdaftar di Bursa Efek Indonesia. Data-data diperoleh dengan menggunakan akses internet ke situs resmi Bursa Efek Indonesia (www.idx.co.id). Waktu pengambilan data dalam penelitian ini pada tahun 2021. Peneliti menggunakan waktu pengamatan pada periode 2016-2020, karena pada tahun tersebut merupakan tahun terbaru dan dapat mempermudah dalam pengumpulan data.

\section{Definisi Operasional Variabel}

\section{Dividend Payout Ratio (Y)}

Dividend payout ratio (DPR) merupakan perbandingan antara dividen per saham yang dibayarkan dengan laba per saham yang didapatkan perusahaan. Semakin tinggi rasio pembayaran dividen (dividend payout ratio) akan menguntungkan untuk pihak investor, tetapi tidak berlaku untuk perusahaan karena akan memperlemah keuangan perusahaan, tetapi sebaliknya semakin rendah dividend payout ratio akan memperkuat keuangan perusahaan dan akan merugikan para investor, karena dividen yang diharapkan investor tidak sesuai yang diharapkan (Samrotun, 2015). Diukur dengan rumus :

$$
D P R=\frac{\text { Dividend Per Share }}{\text { Earning Per Share }}
$$

\section{Return On Asset (X1)}

Return on assets adalah salah satu ukuran profitabilitas perusahaan dalam menghasilkan keuntungan dengan memanfaatkan aset yang digunakan untuk operasi. Posisi dari nilai ROA yang tinggi menunjukkan bahwa perusahaan berkemampuan dalam menghasilkan keuntungan yang berbanding dengan aset yang relatif tinggi (Atmoko et al., 2018). Diukur dengan rumus :

$$
\text { Return On Asset }=\frac{\text { Earning after tax }}{\text { Total Asset }}
$$




\section{Al-Kharaj: Jurnal Ékonomi, Kenangan \& Bisnis Syariah}

\section{Volume 4 No 4 (2022) 1166-1185 P-ISSN 2656-2871 E-ISSN 2656-4351 \\ DOI: $10.47467 /$ alkharaj.v4i4.888}

\section{Growth (X2)}

Pertumbuhan perusahaan merupakan kemampuan perusahaan untuk mengembangkan perusahaan dari waktu ke waktu atau mempertahankan posisi perusahaannya. Pertumbuhan perusahaan dapat dilihat dari total asset perusahaan, semakin besar asset yang dimiliki perusahaan akan menambah hasil operasi dan meningkatkan laba (Novita Sari \& Sudjarni, 2015). Diukur dengan rumus :

$$
\text { Total Asset Growth }=\frac{\left(\text { asset }_{t}-\text { asset }_{t-1}\right)}{\text { asset }_{t-1}}
$$

\section{Free Cash Flow (X2)}

Free cash flow merupakan kas yang berlebih di perusahaan yang seharusnya dibagikan kepada para pemegang saham dalam bentuk dividen. Pembagian tersebut dapat dilakukan setelah perusahaan melakukan pembelanjaan modal (capital expenditure) seperti pembelian aset tetap secara tunai (Prasetio \& Suryono, 2016). Diukur dengan rumus :

\section{Free cash flow $=$ Arus kas dari kegiatan operasional - Pengeluaran modal}

\section{Corporate Governance (Z)}

Tata kelola perusahaan yang baik (Good Corporate Governance) terkait dengan susunan aturan yang menentukan hubungan antara pemegang saham, manajer, kreditor, pemerintah, karyawan dan stakeholder internal maupun eksternal lainnya sesuai dengan hak dan tanggung jawabnya (FCGI, 2011 dalam Ningsih \& Atmaja (2015). Corporate governance diukur menggunakan kepemilikan manajerial. Kepemilikan manajerial merupakan saham yang dimiliki oleh dewan direksi dan dewan komisaris atau pihak manajemen lainnya. Kepemilikan manajerial dijadikan sebagai alat dalam menyelaraskan kepentingan manajemen dan pemilik agar dapat meminimalkan biaya agensi yang terjadi (Noviani et al., 2019). Diukur dengan rumus :

$$
C G=\frac{\text { Jumlah saham yang dimiliki manajemen }}{\text { Jumlah saham yang beredar }}
$$

\section{Uji Kualitas Data}

\section{Uji Statistik Deskriptif}

Uji statistik deskriptif digunakan untuk menunjukkan gambaran mengenai distribusi dan perilaku data sampel. Statistik deskriptif dapat dilihat pada nilai minimum, maksimum, nilai rata-rata (mean), dan standar deviasi (simpangan baku). 


\section{Al-Kharaj: Jurnal Ekonomi, Kenangan \& Bisnis Syariah \\ Volume 4 No 4 (2022) 1166-1185 P-ISSN 2656-2871 E-ISSN 2656-4351 \\ DOI: $10.47467 /$ alkharaj.v4i4.888}

\section{Uji Asumsi Klasik}

\section{Uji Normalitas}

Menurut Ghozali (2018), uji normalitas ini bertujuan untuk menguji apakah dalam model regresi, variabel pengganggu atau residual memiliki distribusi normal. Pada penelitian ini uji normalitas menggunakan uji statistik non-parametrik KolmogorovSmirnoff. Apabila nilai signifikansi yang dihasilkan $>0,05$ maka dapat dikatakan data berdistribusi normal. Dan sebaliknya, jika nilai signifikansi yang dihasilkan $<0,05$ maka data berdistribusi tidak normal.

\section{Uji Multikolinearitas}

Uji multikolinearitas dilakukan untuk menguji apakah model regresi terdapat korelasi antara variabel bebas (independent). Uji multikolinearitas dengan melihat nilai Tolerance dan Variable Inflation Factor (VIF). Dengan nilai Tolerance $\leq 0,10$ atau sama dengan nilai VIF $\geq 10$, maka dapat disimpulkan tidak terjadi multikolinearitas.

\section{Uji Heteroskedastisitas}

Uji Heteroskedastisitas dilakukan untuk menguji model regresi apakah terjadi ketidaksamaan variance dari residual satu pengamatan ke pengamatan yang lain (Ghozali, 2018). Pengujian heteroskedastisitas pada penelitian ini menggunakan metode Spearman's rho dimana tidak terjadi Heteroskedastisitas pada model regresi apabila nilai Sig. $>0,05$.

\section{Uji Autokorelasi}

Uji autokorelasi dilakukan untuk menguji apakah pada model regresi linear terdapat korelasi antara kesalahan pengganggu pada periode $t$ dengan kesalahan pengganggu pada periode t-1 (sebelumnya). Pengujian autokorelasi pada penelitian ini menggunakan Uji Runs Test dengan melihat nilai Asymp. Sig (2-tailed). Jika nilai Asymp. Sig (2-tailed) > 0,05 maka tidak terdapat gejala autokorelasi.

\section{Teknik Analisis Data}

\section{Analisis Regresi Linear Berganda}

Menurut Ghozali (2018), analisis regresi linear berganda digunakan untuk mengetahui arah dan seberapa besar pengaruh variabel independen terhadap variabel dependen. Persamaan regresi linear berganda untuk menguji pengaruh Return On Assets (ROA), Growth, dan Free Cash Flow (FCF) terhadap Dividend Payout Ratio (DPR) dengan Corporate Governance (CG) sebagai variabel intervening dapat dinyatakan dalam bentuk formula sebagai berikut :

$$
\begin{aligned}
& Z=\alpha+\beta_{1} X_{1}+\beta_{2} X_{2}+ß_{3} X_{3}+e \\
& \hat{Y}=\alpha+B_{1} X_{1}+B_{2} X_{2}+ß_{3} X_{3}+B_{z} Z+e
\end{aligned}
$$




\title{
Al-Kharaj: Jurnal Ekonomi, Kenangan \& Bisnis Syariah
}

Volume 4 No 4 (2022) 1166-1185 P-ISSN 2656-2871 E-ISSN 2656-4351

DOI: 10.47467/alkharaj.v4i4.888

\author{
Keterangan : \\ $\hat{Y}=$ Prediksi Dividend Payout Ratio \\ $\mathrm{Z}$ = Corporate Governance \\ $\alpha=$ Konstanta \\ $ß=$ Koefisien regresi dari masing-masing variabel \\ $\mathrm{X} 1=$ Return on Asset $(\mathrm{ROA})$ \\ $\mathrm{X} 2$ = Asset Growth \\ $\mathrm{X} 3=$ Free Cash Flow (FCF)
}

Uji T

Uji statistik t digunakan untuk mengetahui pengaruh variabel independen secara parsial. Uji $t$ dapat dilakukan dengan membandingkan nilai $t$ hitung dengan $t$ tabel atau dengan membandingkan nilai signifikan dengan nilai signifikan yang sudah ditentukan yaitu 0,05. Pada penelitian ini uji t dilakukan dengan membandingkan nilai signifikan yang sudah ditentukan yaitu 0,05 .

\section{Uji Koefisien Determinasi ( $\left.\mathbf{R}^{2}\right)$}

Uji koefisien determinasi bertujuan untuk mengukur seberapa jauh kemampuan model dalam menerangkan variasi variabel dependen (Ghozali, 2018). Nilai $\mathrm{R}^{2}$ yang kecil berarti kemampuan variabel-variabel independen dalam menjelaskan variabel-variabel dependen amat terbatas.

\section{Analisis Jalur (Path Analysis)}

Untuk menguji pengaruh variabel intervening menggunakan metode analisis jalur (Path Analysis). Analisis jalur adalah penggunaan analisis regresi untuk menaksir hubungan kausalitas antar variabel yang telah ditetapkan sebelumnya berdasarkan teori (Ghozali, 2018). Apabila nilai koefisien regresi hasil perhitungan pengaruh tidak langsung lebih besar dari perhitungan pengaruh langsung maka dapat disimpulkan bahwa variabel intervening mampu menjelaskan variabel dependen yang artinya ada mediasi (variabel intervening diterima), dan sebaliknya.

\section{Kerangka Pikir}


A1-Kharaj: Jurval Ekgonomi, Kenangan ₹ Bisnis Syariah

Volume 4 No 4 (2022) 1166-1185 P-ISSN 2656-2871 E-ISSN 2656-4351

DOI: $10.47467 /$ alkharaj.v4i4.888

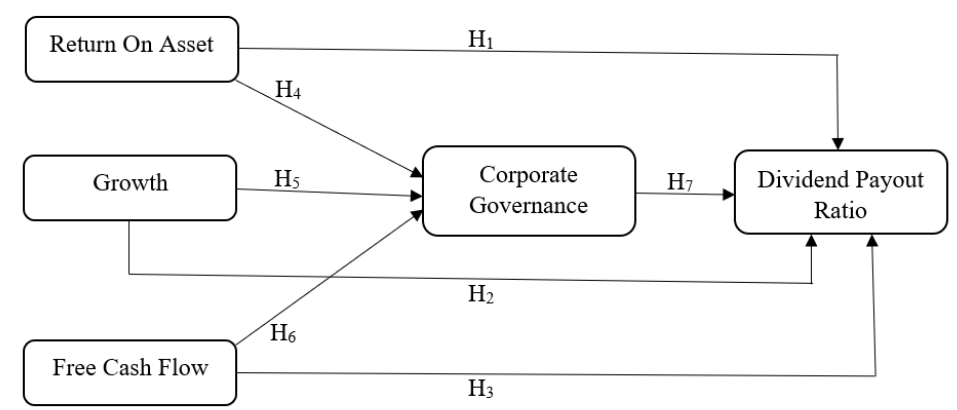

\section{Hipotesis Penelitian}

$\mathrm{H}_{1}$ : ROA berpengaruh positif terhadap DPR.

$\mathrm{H}_{2}$ : Growth berpengaruh positif terhadap DPR.

$\mathrm{H}_{3}$ : FCF berpengaruh positif terhadap DPR.

$\mathrm{H}_{4}:$ ROA berpengaruh positif terhadap CG.

$\mathrm{H}_{5}$ : Growth berpengaruh positif terhadap CG.

$\mathrm{H}_{6}$ : FCF berpengaruh positif terhadap CG.

$\mathrm{H}_{7}$ : CG berpengaruh positif terhadap DPR.

\section{HASIL DAN PEMBAHASAN}

\section{Uji Normalitas}

Tabel 1. Uji Normalitas Persamaan I One-Sample Kolmogorov-Smirnov Test

\begin{tabular}{|ll|r|}
\hline & & $\begin{array}{c}\text { Unstandardized } \\
\text { Residual }\end{array}$ \\
\hline $\mathrm{N}$ & Mean & 53 \\
& Std. & .0000000 \\
& Deviation & 19.58762115 \\
Most Extreme Differences & Absolute & .086 \\
& Positive & .086 \\
& Negative & -.065 \\
Test Statistic & & .086 \\
Asymp. Sig. (2-tailed) & & $.200 \mathrm{c,d}$ \\
\hline
\end{tabular}




\section{Al-Kharaj: Jurual Ékonomi, Kenangan \& Bisnis Syariah}

\section{Volume 4 No 4 (2022) 1166-1185 P-ISSN 2656-2871 E-ISSN 2656-4351 \\ DOI: $10.47467 /$ alkharaj.v4i4.888}

Berdasarkan tabel diatas, dapat dilihat bahwa uji normalitas menunjukkan level signifikan sebesar 0,200 yang berarti nilai signifikan tersebut lebih besar dari 0,05 yaitu $0,200>0,05$. Sehingga dapat disimpulkan bahwa data terdistribusi normal.

Tabel 2. Uji Normalitas Persamaan II

One-Sample Kolmogorov-Smirnov Test

\begin{tabular}{|ll|r|}
\hline & & $\begin{array}{c}\text { Unstandardized } \\
\text { Residual }\end{array}$ \\
\hline $\mathrm{N}$ & Mean & 53 \\
Normal Parameters ${ }^{\mathrm{a}, \mathrm{b}}$ & Std. Deviation & .0000000 \\
& Absolute & .82658483 \\
Most Extreme Differences & Positive & .060 \\
& Negative & -.060 \\
& & .060 \\
Test Statistic & & $.200 \mathrm{c,d}$ \\
Asymp. Sig. (2-tailed) & &
\end{tabular}

Berdasarkan tabel diatas, dapat dilihat bahwa uji normalitas menunjukkan level signifikan sebesar 0,200 yang berarti nilai signifikan tersebut 0,200 $>0,05$ maka dapat disimpulkan bahwa data terdistribusi normal.

\section{Uji Multikolinearitas}

Tabel 3. Uji Multikolinearitas Persamaan I

\begin{tabular}{|l|l|r|r|}
\hline \multirow{2}{*}{\multicolumn{2}{|l|}{ Model }} & \multicolumn{2}{|c|}{ Collinearity Statistics } \\
\cline { 3 - 4 } & (Constant) & Tolerance & \multicolumn{1}{c|}{ VIF } \\
\hline \multirow{1}{*}{1} & ROA & .821 & 1.218 \\
& GROWTH & .921 & 1.085 \\
& FCF & .860 & 1.163 \\
\hline \multicolumn{2}{|l|}{ a. Dependent Variable: CG }
\end{tabular}

Pada tabel diatas, menunjukkan nilai Tolerance $>0,10$ dan VIF $<10$. Maka dapat disimpulkan bahwa pada penelitian ini tidak terjadi multikolinearitas.

Tabel 4. Uji Multikolinearitas Persamaan II

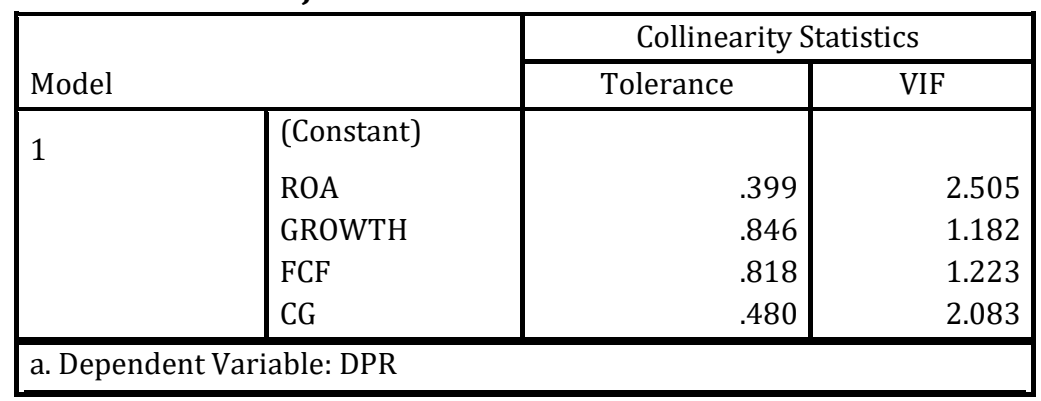

Pada tabel diatas menunjukkan nilai Tolerance $>0,10$ dan VIF $<10$. Maka dapat disimpulkan bahwa pada penelitian ini tidak terjadi multikolinearitas.

\section{Uji Heteroskedastisitas}




\section{Al-Kharaj: Jurnal Ekonomi, Kenangan \& Bisnis Syariah}

Volume 4 No 4 (2022) 1166-1185 P-ISSN 2656-2871 E-ISSN 2656-4351

DOI: $10.47467 /$ alkharaj.v4i4.888

Tabel 5. Uji Heteroskedastisitas Persamaan I

\begin{tabular}{|c|c|c|c|}
\hline & & & $\begin{array}{c}\text { Unstandardized } \\
\text { Residual }\end{array}$ \\
\hline Spearman's rho & $\begin{array}{l}\text { ROA } \\
\text { GROWTH } \\
\text { FCF } \\
\text { Unstandardized } \\
\text { Residual }\end{array}$ & $\begin{array}{l}\text { Correlation } \\
\text { Coefficient } \\
\text { Sig. (2- } \\
\text { tailed) } \\
\mathrm{N} \\
\text { Correlation } \\
\text { Coefficient } \\
\text { Sig. (2- } \\
\text { tailed) } \\
\mathrm{N} \\
\text { Correlation } \\
\text { Coefficient } \\
\text { Sig. (2- } \\
\text { tailed) } \\
\mathrm{N} \\
\text { Correlation } \\
\text { Coefficient } \\
\text { Sig. (2- } \\
\text { tailed) } \\
\mathrm{N}\end{array}$ & $\begin{array}{r}-.033 \\
.814 \\
53 \\
.062 \\
.658 \\
53 \\
-.023 \\
.869 \\
53 \\
1.000 \\
. \\
53\end{array}$ \\
\hline
\end{tabular}

Berdasarkan tabel di atas dapat dilihat bahwa hasil perhitungan dari masingmasing variabel independen menunjukkan nilai Sig. $>0,05$ yaitu 0,814 untuk variabel ROA, 0,658 untuk variabel Growth, dan 0,869 untuk variabel FCF. Maka dapat disimpulkan bahwa penelitian ini tidak terjadi masalah heteroskedastisitas.

Tabel 6. Uji Heteroskedastisitas Persamaan II

\begin{tabular}{|c|c|c|c|}
\hline & & & $\begin{array}{c}\text { Unstandardized } \\
\text { Residual }\end{array}$ \\
\hline \multirow[t]{3}{*}{ Spearman's rho } & ROA & $\begin{array}{l}\text { Correlation } \\
\text { Coefficient } \\
\text { Sig. (2- } \\
\text { tailed) } \\
\text { N }\end{array}$ & $\begin{array}{r}.023 \\
.868 \\
53\end{array}$ \\
\hline & GROWTH & $\begin{array}{l}\text { Correlation } \\
\text { Coefficient } \\
\text { Sig. (2- } \\
\text { tailed) } \\
\mathrm{N}\end{array}$ & $\begin{array}{r}.052 \\
.713 \\
53\end{array}$ \\
\hline & FCF & $\begin{array}{l}\text { Correlation } \\
\text { Coefficient } \\
\text { Sig. (2- } \\
\text { tailed) } \\
\text { N }\end{array}$ & $\begin{array}{r}.014 \\
.921 \\
53\end{array}$ \\
\hline
\end{tabular}




\section{Al-Kharaj: Jurnal Ékonomi, Kenangan \& Bisnis Syariah}

Volume 4 No 4 (2022) 1166-1185 P-ISSN 2656-2871 E-ISSN 2656-4351

DOI: 10.47467/alkharaj.v4i4.888

\begin{tabular}{|l|l|l|r|}
\hline CG & $\begin{array}{l}\text { Correlation } \\
\text { Coefficient }\end{array}$ & .010 \\
& Sig. (2- & .942 \\
tailed) & $\mathrm{N}$ & 53 \\
\hline & Unstandardized & Correlation & 1.000 \\
Residual & $\begin{array}{l}\text { Coefficient } \\
\text { Sig. (2- }\end{array}$ & \\
& tailed) & \\
& $\mathrm{N}$ & 53 \\
\hline
\end{tabular}

Berdasarkan tabel di atas dapat dilihat bahwa hasil perhitungan dari masingmasing variabel independen menunjukkan nilai Sig. $>0,05$ yaitu 0,868 untuk variabel ROA, 0,713 untuk variabel Growth, 0,921 untuk variabel FCF, dan 0,942 untuk variabel CG. Maka dapat disimpulkan bahwa penelitian ini tidak terjadi masalah heteroskedastisitas.

\section{Uji Autokorelasi}

Tabel 7. Uji Autokorelasi Persamaan I

\begin{tabular}{|l|r|}
\hline \multicolumn{2}{|c|}{ Runs Test } \\
\hline Test Valuea & Unstandardized Residual \\
Cases < Test Value & .31083 \\
Cases $>=$ Test Value & 26 \\
Total Cases & 26 \\
Number of Runs & 52 \\
Z & 21 \\
Asymp. Sig. (2-tailed) & -1.681 \\
\hline
\end{tabular}

Pada tabel diatas menunjukkan bahwa nilai Asymp. Sig (2-tailed) lebih besar dari 0,05 yaitu $0,093>0,05$. Sehingga dapat disimpulkan bahwa pada model regresi persamaan I yang digunakan pada penelitian ini tidak terjadi autokorelasi.

Tabel 8. Uji Autokorelasi Persamaan II

\begin{tabular}{|l|r|}
\hline \multicolumn{2}{|c}{ Runs Test } \\
\hline Test Valuea $^{\mathrm{a}}$ & Unstandardized Residual \\
Cases < Test Value & -.00396 \\
Cases >= Test Value & 26 \\
Total Cases & 27 \\
Number of Runs & 53 \\
Z & 23 \\
\hline
\end{tabular}




\section{Al-Kharaj: Jurnal Ekonomi, Kenangan \& Bisnis Syariah}

Volume 4 No 4 (2022) 1166-1185 P-ISSN 2656-2871 E-ISSN 2656-4351

DOI: 10.47467/alkharaj.v4i4.888

\section{\begin{tabular}{l|l} 
Asymp. Sig. (2-tailed) & .213
\end{tabular}}

Pada tabel diatas menunjukkan nilai Asymp. Sig (2-tailed) lebih kecil dari 0,05 yaitu $0,001<0,05$. Maka dapat dikatakan bahwa pada model regresi persamaan II tidak terjadi autokorelasi.

\section{Teknik Analisis Data}

\section{Analisis Regresi Linear Berganda}

Tabel 9. Analisis Regresi Persamaan I

\begin{tabular}{|l|l|r|r|r|r|r|}
\hline \multicolumn{2}{|c|}{} & \multicolumn{2}{|c|}{$\begin{array}{c}\text { Unstandardized } \\
\text { Coefficients }\end{array}$} & $\begin{array}{c}\text { Standardized } \\
\text { Coefficients }\end{array}$ & \\
\cline { 3 - 7 } \multicolumn{2}{|c|}{ Model } & \multicolumn{1}{c|}{ B } & Std. Error & Beta & \multicolumn{1}{c|}{ t } & \multicolumn{1}{c|}{ Sig. } \\
\hline \multirow{2}{*}{1} & (Constant) & -3.175 & 5.745 & & -.553 & .583 \\
& ROA & 3.410 & .474 & .786 & 7.192 & .000 \\
& GROWTH & -101.785 & 48.810 & -.215 & -2.085 & .042 \\
& FCF & -.008 & .005 & -.169 & -1.583 & .120 \\
\hline
\end{tabular}

Tabel 10. Analisis Regresi Persamaan II

\begin{tabular}{|l|l|r|r|r|r|r|}
\hline \multicolumn{2}{|c|}{} & \multicolumn{2}{|c|}{$\begin{array}{c}\text { Unstandardized } \\
\text { Coefficients }\end{array}$} & $\begin{array}{c}\text { Standardized } \\
\text { Coefficients }\end{array}$ & \\
\cline { 3 - 5 } \multicolumn{2}{|l|}{ Model } & \multicolumn{1}{c|}{ B } & Std. Error & \multicolumn{1}{c|}{ Beta } & \multicolumn{1}{c|}{$\mathrm{t}$} & \multicolumn{1}{c|}{ Sig. } \\
\hline 1 & (Constant) & 22.643 & 3.813 & & 5.938 & .000 \\
& ROA & 3.259 & .450 & .915 & 7.245 & .000 \\
& GROWTH & -107.338 & 33.696 & -.276 & -3.185 & .003 \\
& FCF & -.009 & .003 & -.219 & -2.480 & .017 \\
& CG & -.005 & .095 & -.006 & -.056 & .955 \\
\hline
\end{tabular}

Dari tabel diatas dapat dirumuskan persamaan regresi linear berganda sebagai berikut :

$$
\begin{aligned}
& \mathrm{Z}=-3,175+3,410 \mathrm{ROA}-101,785 \mathrm{GROWTH}-\mathrm{0,008FCF}+\mathrm{e} \\
& \hat{\mathrm{Y}}=22,643+3,259 \mathrm{ROA}-107,338 \mathrm{GROWTH}-0,009 \mathrm{FCF}-0,005 \mathrm{CG}+\mathrm{e}
\end{aligned}
$$

Dari persamaan diatas dapat diuraikan sebagai berikut :

a. Besarnya nilai ROA pada persamaan I yaitu 3,410 yang menunjukkan bahwa variabel ROA memiliki dampak positif pada CG. Jika ROA naik maka akan meningkatkan CG.

b. Besarnya nilai Growth pada persamaan I yaitu -101,785 yang menunjukkan bahwa variabel Growth memiliki dampak negatif pada CG. Jika Growth naik maka akan menurunkan CG.

c. Besarnya nilai FCF pada persamaan I yaitu $-0,008$ yang menunjukkan bahwa variabel FCF memiliki dampak negatif pada CG. Jika FCF naik maka akan menurunkan CG. 


\section{Al-Kharaj: Jurnal Ekonomi, Kenangan \& Bisnis Syariah}

\section{Volume 4 No 4 (2022) 1166-1185 P-ISSN 2656-2871 E-ISSN 2656-4351 DOI: $10.47467 /$ alkharaj.v4i4.888}

d. Besarnya nilai ROA pada persamaan II yaitu 3,259 yang menunjukkan bahwa variabel ROA memiliki dampak positif pada DPR. Jika ROA naik maka akan meningkatkan DPR.

e. Besarnya nilai Growth pada persamaan II yaitu -107,338 yang menunjukkan bahwa variabel Growth memiliki dampak negatif pada DPR. Jika Growth naik maka akan menurunkan DPR.

f. Besarnya nilai FCF pada persamaan II yaitu -0,009 yang menunjukkan bahwa variabel FCF memiliki dampak negatif pada DPR. Jika FCF naik maka akan menurunkan DPR.

g. Besarnya nilai CG pada persamaan II yaitu $-0,005$ yang menunjukkan bahwa variabel CG memiliki dampak negatif pada DPR. Jika CG naik maka akan menurunkan DPR.

\section{Uji T (Uji Hipotesis secara Parsial)}

a. Berdasarkan tabel 10 menunjukkan ROA memiliki nilai koefisien regresi sebesar 3,259 dengan nilai signifikan sebesar $0,000<0,05$. Hal ini berarti bahwa variabel ROA berpengaruh positif dan signifikan terhadap DPR.

b. Berdasarkan tabel 10 menunjukkan Growth memiliki nilai koefisien regresi sebesar -107,338 dengan nilai signifikan sebesar 0,003<0,05. Hal ini berarti bahwa variabel Growth berpengaruh negatif dan signifikan terhadap DPR.

c. Berdasarkan tabel 10 menunjukkan FCF memiliki nilai koefisien regresi sebesar $-0,009$ dengan nilai signifikan sebesar $0,017<0,05$. Hal ini berarti bahwa variabel FCF berpengaruh negatif dan signifikan terhadap DPR.

d. Berdasarkan tabel 11 menunjukkan ROA memiliki nilai koefisien regresi sebesar 3,410 dengan nilai signifikan sebesar $0,000<0,05$. Hal ini berarti bahwa variabel ROA berpengaruh positif dan signifikan terhadap CG.

e. Berdasarkan tabel 11 menunjukkan Growth memiliki nilai koefisien regresi sebesar -101,785 dengan nilai signifikan sebesar 0,042<0,05. Hal ini berarti bahwa variabel Growth berpengaruh negatif dan signifikan terhadap CG.

f. Berdasarkan tabel 11 menunjukkan FCF memiliki nilai koefisien regresi sebesar $-0,008$ dengan nilai signifikan sebesar 0,120 >0,05. Hal ini berarti bahwa variabel FCF berpengaruh negatif dan tidak signifikan terhadap CG.

g. Berdasarkan tabel 10 menunjukkan CG memiliki nilai koefisien regresi sebesar 0,005 dengan nilai signifikan sebesar $0,955>0,05$. Hal ini berarti bahwa variabel CG berpengaruh negatif dan tidak signifikan terhadap DPR.

\section{Uji Koefisien Determinasi $\left(\mathrm{R}^{\mathbf{2}}\right)$}

Tabel 11. Uji Koefisien Determinasi Persamaan I

\begin{tabular}{|l|c|r|r|c|}
\hline Model & $\mathrm{R}$ & R Square & $\begin{array}{c}\text { Adjusted R } \\
\text { Square }\end{array}$ & $\begin{array}{c}\text { Std. Error of the } \\
\text { Estimate }\end{array}$ \\
\hline 1 & $.721^{\mathrm{a}}$ & .520 & .491 & 20.17833 \\
\hline
\end{tabular}




\section{Al-Kharaj: Jurnal Ekonomi, Kenangan \& Bisnis Syariah}

\section{Volume 4 No 4 (2022) 1166-1185 P-ISSN 2656-2871 E-ISSN 2656-4351 DOI: $10.47467 /$ alkharaj.v4i4.888}

Berdasarkan tabel diatas, nilai koefisien determinasi (Adjusted $R^{2}$ ) pada output menunjukkan nilai sebesar 0,491 atau jika dalam presentase sebesar 49,1\%. Nilai tersebut bermakna bahwa variabel bebas yaitu Return On Assets (ROA), growth, dan Free Cash Flow (FCF) dalam mempengaruhi Corporate Governance sebesar 49,1\% sedangkan sisanya $50,9 \%$ dipengaruhi oleh faktor lain yang tidak diteliti dalam penelitian ini.

Tabel 12. Uji Koefisien Determinasi Persamaan II

\begin{tabular}{|l|c|r|c|c|}
\hline Model & $\mathrm{R}$ & R Square & $\begin{array}{c}\text { Adjusted R } \\
\text { Square }\end{array}$ & $\begin{array}{c}\text { Std. Error of the } \\
\text { Estimate }\end{array}$ \\
\hline 1 & $.833^{\mathrm{a}}$ & .694 & .669 & 13.35033 \\
\hline
\end{tabular}

Berdasarkan tabel diatas, nilai koefisien determinasi (Adjusted R2) pada output menunjukkan nilai sebesar 0,669 atau jika dalam presentase sebesar 66,9\%. Nilai tersebut bermakna bahwa variabel bebas yaitu Return On Assets (ROA), growth, Free Cash Flow (FCF), dan Corporate Governance dalam mempengaruhi Dividend Payout Ratio (DPR) sebesar 66,9\% sedangkan sisanya 33,1\% dipengaruhi oleh faktor lain yang tidak diteliti dalam penelitian ini.

\section{Analisis Jalur (Path Analysis)}

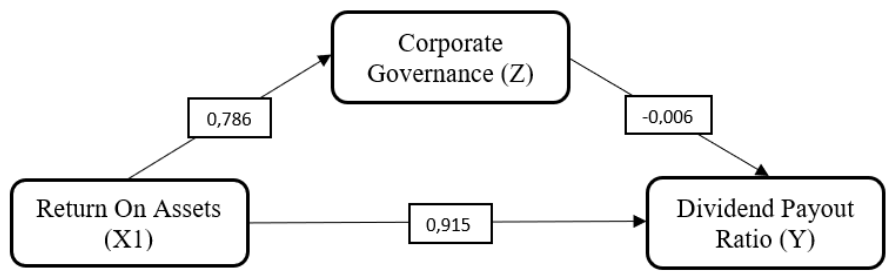

Gambar 1. Analisis Jalur Model I

Gambar 1 menunjukkan bahwa nilai pengaruh tidak langsung melalui Corporate Governance lebih kecil dari nilai pengaruh langsung ROA terhadap DPR. Sehingga dapat disimpulkan bahwa Corporate Governance tidak mampu menjadi variabel yang memediasi pengaruh antara ROA terhadap DPR.

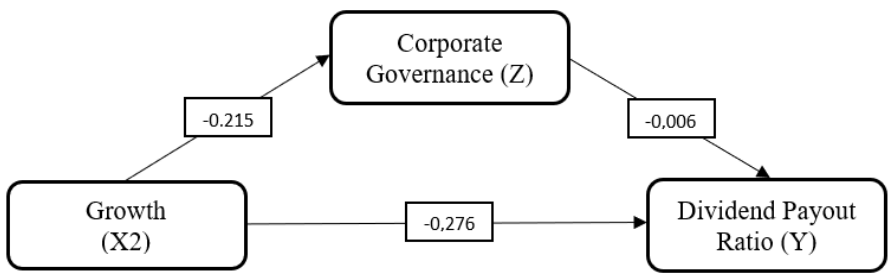

Gambar 2. Analisis Jalur Model II

Gambar 2 menunjukkan bahwa nilai pengaruh tidak langsung melalui Corporate Governance lebih besar dari nilai pengaruh langsung Growth terhadap DPR. Sehingga 


\section{A1-Kharaj: Jurual Ékonomi, Kenangan \& Bisnis Syariah \\ Volume 4 No 4 (2022) 1166-1185 P-ISSN 2656-2871 E-ISSN 2656-4351 DOI: $10.47467 /$ alkharaj.v4i4.888}

dapat disimpulkan bahwa Corporate Governance mampu menjadi variabel yang memediasi pengaruh antara Growth terhadap DPR.

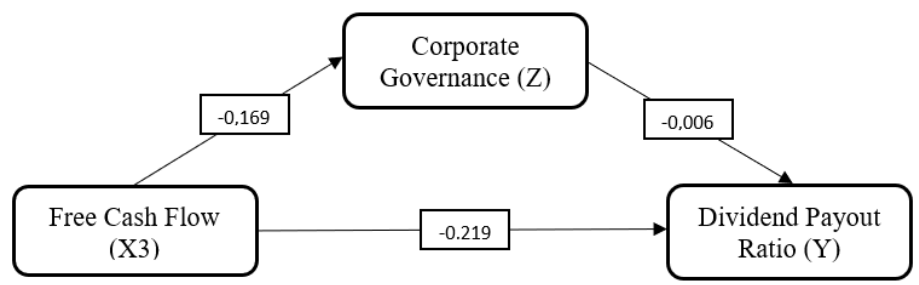

Gambar 3. Analisis Jalur Model III

Gambar 3 menunjukkan bahwa nilai pengaruh tidak langsung melalui Corporate Governance lebih besar dari nilai pengaruh langsung FCF terhadap DPR. Sehingga dapat disimpulkan bahwa Corporate Governance mampu menjadi variabel yang memediasi pengaruh antara Growth terhadap DPR.

\section{KESIMPULAN DAN SARAN}

\section{Kesimpulan}

1. Return On Assets (ROA) berpengaruh positif dan signifikan terhadap Dividend Payout Ratio (DPR). Hal ini terbukti dari hasil Uji T yang menunjukkan Return On Assets (ROA) memiliki nilai koefisien regresi sebesar 3,259 dengan nilai signifikan sebesar $0,000<0,05$.

2. Growth berpengaruh negatif dan signifikan terhadap Dividend Payout Ratio (DPR). Hal ini terbukti dari hasil Uji T yang menunjukkan Growth memiliki nilai koefisien regresi sebesar $-107,338$ dengan nilai signifikan sebesar 0,003 $<0,05$.

3. Free cash flow berpengaruh negatif dan signifikan terhadap Dividend Payout Ratio (DPR). Hal ini terbukti dari hasil Uji T yang menunjukkan Free Cash Flow (FCF) memiliki nilai koefisien regresi sebesar -0,009 dengan nilai signifikan sebesar $0,017<0,05$.

4. Return On Assets (ROA) berpengaruh positif dan signifikan terhadap Corporate Governance (CG). Hal ini terbukti dari hasil Uji T yang menunjukkan Return On Assets (ROA) memiliki nilai koefisien regresi sebesar 3,410 dengan nilai signifikan sebesar $0,000<0,05$.

5. Growth berpengaruh negatif dan signifikan terhadap Corporate Governance (CG). Hal ini terbukti dari hasil Uji T yang menunjukkan Growth memiliki nilai koefisien regresi sebesar -101,785 dengan nilai signifikan sebesar 0,042<0,05.

6. Free cash flow tidak berpengaruh signifikan terhadap Corporate Governance (CG). Hal ini terbukti dari hasil Uji T yang menunjukkan Free Cash Flow (FCF) memiliki nilai koefisien regresi sebesar -0,008 dengan nilai signifikan sebesar 0,120>0,05.

7. Corporate governance tidak berpengaruh signifikan terhadap Dividend Payout Ratio (DPR). Hal ini terbukti dari hasil Uji T yang menunjukkan Corporate 


\section{A1-Kharaj: Jurnal Ekgonomi, Kenangan \& Bisnis Syariah}

\section{Volume 4 No 4 (2022) 1166-1185 P-ISSN 2656-2871 E-ISSN 2656-4351 DOI: 10.47467/alkharaj.v4i4.888}

Governance (CG) memiliki nilai koefisien regresi sebesar $-0,005$ dengan nilai signifikan sebesar 0,955 >0,05.

8. Berdasarkan hasil analisis jalur (Path Analysis), dalam penelitian ini penulis gagal membuktikan adanya variabel intervening pada model 1 (satu), namun peneliti berhasil membuktikan adanya variabel intervening pada model 2 (dua) dan 3 (tiga).

a. Pada model 1, nilai pengaruh tidak langsung melalui Corporate Governance lebih kecil dari nilai pengaruh langsung ROA terhadap DPR yaitu $-0,005<0,915$. Sehingga dapat disimpulkan bahwa pengaruh ROA terhadap DPR melalui corporate governance sebagai variabel intervening ditolak.

b. Pada model 2, nilai pengaruh tidak langsung melalui Corporate Governance lebih besar dari nilai pengaruh langsung Growth terhadap DPR yaitu 0,001 > 0,276 . Sehingga dapat disimpulkan bahwa pengaruh growth terhadap DPR melalui corporate governance sebagai variabel intervening diterima.

c. Pada model 3, nilai pengaruh tidak langsung melalui Corporate Governance lebih besar dari nilai pengaruh langsung FCF terhadap DPR yaitu 0,001 >-0,219. Sehingga dapat disimpulkan bahwa pengaruh FCF terhadap DPR melalui corporate governance sebagai variabel intervening diterima.

\section{Saran}

1. Bagi Perusahaan

Kinerja keuangan yang tunjukkan oleh besarnya ROA dapat dijadikan faktor pertimbangan oleh investor untuk membuat keputusan dalam menginvestasikan modalnya. Sehingga perusahaan harus memperhatikan pola kinerja keuangannya agar mampu menghasilkan keuntungan dan dapat meningkatkan profitabilitasnya. Disamping itu penerapan CG juga perlu diperhatikan agar terciptanya keseimbangan antara berbagai kepentingan yang dapat bermanfaat bagi perusahaan secara menyeluruh.

2. Bagi Investor

Dalam membuat keputusan investasi, investor harus mempertimbangkan berbagai faktor dalam menganalisis kinerja keuangan dan prospek perusahaan agar memberikan keuntungan dalam berinvestasi terutama pada pembayaran dividen.

3. Bagi Peneliti Selanjutnya

Penelitian selanjutnya dapat menggunakanan variabel independent lain untuk memprediksi DPR, misalnya seperti leverage, likuiditas, dan aktivitas perusahaan. Selain itu, penelitian selanjutnya diharapkan untuk memberikan kekuatan generalisasi dengan menambah rentang waktu pengamatan atau menggunakan seluruh sektor industri.

\section{DAFTAR PUSTAKA}




\section{A1-Kharaj: Jurual Ékonomi, Kenangan \& Bisnis Syariah \\ Volume 4 No 4 (2022) 1166-1185 P-ISSN 2656-2871 E-ISSN 2656-4351 DOI: 10.47467/alkharaj.v4i4.888}

Adnan, M. A., Gunawan, B., \& Candrasari, R. (2014). Pengaruh Profitabilitas, Leverage, Growth, dan Free Cash Flow Terhadap Dividend Payout Ratio Perusahaan dengan Mempertimbangkan Corporate Governance sebagai Variabel Intervening. Jaai, 18(2), 89-100.

Atmoko, Y., Defung, F., \& Tricahyadinata, I. (2018). Pengaruh return on assets, debt to equity ratio, dan firm size terhadap dividend payout ratio. Kinerja, 14(2), 103. https://doi.org/10.29264/jkin.v14i2.2486

Bintara, R. (2018). PENGARUH PROFITABILITAS, GROWTH OPPORTUNITY, DAN STRUKTUR MODAL TERHADAP NILAI PERUSAHAAN DENGAN GOOD CORPORATE GOVERNANCE SEBAGAI VARIABEL PEMODERASI. Profita: Komunikasi Ilmiah Akuntansi Dan Perpajakan, http://publikasi.mercubuana.ac.id/index.php/profita

Cahyadi, R. T., Purwanti, L., \& Mardiati, E. (2018). Pengaruh Profitabilitas, Dewan Komisaris, Komisaris Independen Dan Risiko Idiosinkratis Terhadap Dividend $\begin{array}{llll}\text { Payout Ratio. } & \text { Economia, } & \text { 14(1), }\end{array}$ https://doi.org/10.21831/economia.v14i1.19404

Demirgüneș, K., \& Üniversitesi, A. E. (2015). Determinants of Target Dividend Payout Ratio: A Panel Autoregressive Distributed Lag Analysis International Journal of Economics and Financial Issues Determinants of Target Dividend Payout Ratio: A Panel Autoregressive Distributed Lag Analysis. International Journal of Economics and Financial Issues, 5(2), 418-426. http:www.econjournals.com

Dwi, S., \& Ambarwati, A. (2014). Perspektif Bird in the Hand : Penentu. Jurnal Keuangan Dan Perbankan, 18(3), 345-357.

Ghozali, I. (2018). Aplikasi Analisis Multivariete Dengan Program IBM SPSS 25 (9th ed.) Badan Penerbit Universitas Diponegoro.

Hanif, M., \& Bustaman. (2017). Pengaruh Debt to Equity Ratio, Return On Asset, Firm Size dan Earning Pe Share Terhadap Dividend Payout Ratio. Jurnal Ilmiah Mahasiswa Ekonomi Akuntansi, 2(1), 73-81.

Hardani, Andriani, H., Auliya, N. H., Fardani, R. A., Ustiawaty, J., Utami, E. F., Sukmana, D. J., \& Istiqomah, R. R. (2020). Buku Metode Penelitian Kualitatif dan Kuantitatif (Issue March). CV. Pustaka Ilmu Group.

Hossain, F., Sheikh, R., \& Akterujjaman, S. M. (2014). Impact of Firm Specific Factors on Cash Dividend Payment Decisions: Evidence from Bangladesh. International Review of Business Research Papers, 10(2), 62-80. https://doi.org/10.21102/irbrp.2014.09.102.05 


\section{Al-Kharaj: Jurual Ekonomi, Kenangan है Bisnis Syariah Volume 4 No 4 (2022) 1166-1185 P-ISSN 2656-2871 E-ISSN 2656-4351 DOI: 10.47467/alkharaj.v4i4.888}

Khan, R., Meer, J., Lodhi, R., \& Aftab, F. (2017). Determinants of Dividend Payout Ratio: a Study of Kse Manufacturing Firms in Pakistan. IBT Journal of Business Studies (JBS), 13(1), 13-2.

Kusuma, P. J., Hartoyo, S., \& Sasongko, H. (2018). Analysis of Factors that Influence Dividend Payout Ratio of Coal Companies in Indonesia Stock Exchange. Jurnal Dinamika Manajemen, 9(2), 189-197. https://doi.org/10.15294/jdm.v9i2.16417

Labhane, N. B. (2015). Determinants of Dividend Payout Ratio: Evidence from Indian Companies. Business and Economic Research, Vol 5(No 2). https://doi.org/10.15548/jt.v22i1.137

Laim, W., Nangoy, S., \& Murni, S. (2015). Analisis Faktor-Faktor Yang Mempengaruhi Dividend Payout Ratio Pada Perusahaan Yang Terdaftar Di Indeks Lq-45 Bursa Efek Indonesia. Jurnal Riset Ekonomi, Manajemen, Bisnis Dan Akuntansi, 3(1), 1129-1140. https://doi.org/10.35794/emba.v3i1.7927

Mahaputra, G., \& Wirawati, N. (2014). Pengaruh Faktor Keuangan Dan Ukuran Perusahaan Pada Dividend Payout Ratio Perusahaan Perbankan. E-Jurnal Akuntansi, 9(3), 695-708.

Ningsih, F. S., \& Atmaja, A. S. (2015). Pengaruh Pengungkapan Good Corporate Governance terhadap Stock Return dengan Kinerja Perusahaan sebagai Variabel Mediasi pada Perusahaan LQ-45. Business Accounting Review, 5(2), 433-444.

Noviani, A. V., Dorkas, A., Atahau, R., Robiyanto, R., \& Artikel, R. (2019). Struktur modal, profitabilitas, dan nilai perusahaan: Efek moderasi Good Corporate Governance I N F 0 A R T I K E L. Jurnal Ekonomi Dan Bisnis, 22(Oktober), 391-415.

Novita Sari, K., \& Sudjarni, L. (2015). Pengaruh Likuiditas, Leverage, Pertumbuhan Perusahaan, Dan Profitabilitas Terhadap Kebijakan Dividen Pada Perusahaan Manufaktur Di Bei. E-Jurnal Manajemen Universitas Udayana, 4(10), 255134.

Parera, D. (2016). Pengaruh Net Profit Margin ( Npm ), Return on Asset ( Roa ), Dan Debt To Equity Ratio ( Der ) Terhadap Dividend Payout Ratio ( Dpr ) Pada Perusahaan Yang Tercatat Dalam Indeks Lq45 Di Bei Periode 2009-2013 . Jurnal EMBA, 4(2), 538-548.

Parsian, H., \& Koloukhi, A. S. (2014). A study on the effect of free cash flow and profitability current ratio on dividend payout ratio: Evidence from Tehran Stock Exchange. Management Science Letters, 63-70. https://doi.org/10.5267/j.msl.2013.11.033

Prasetio, D. A., \& Suryono, B. (2016). PENGARUH PROFITABILITAS, FREE CASH FLOW, INVESTMENT OPPORTUNITY SET TERHADAP DIVIDEND PAYOUT RATIO. Jurnal Ilmu Dan Riset Akuntansi, 5. https://doi.org/10.1007/s001860100128 


\section{A1-Kharaj: Jurual Ékonomi, Kenangan \& Bisnis Syariah \\ Volume 4 No 4 (2022) 1166-1185 P-ISSN 2656-2871 E-ISSN 2656-4351 \\ DOI: $10.47467 /$ alkharaj.v4i4.888}

Putri, R. A., \& Rokhim, R. (2016). The Effect of Ownership Structure and Cash Flow to the Non-financial Firms' Dividend Payout Ratio Listed in Idx. MIX: Jurnal Ilmiah Manajemen, VI. https://mix.mercubuana.ac.id/publications/154139/the-effect-ofownership-structure-and-cash-flow-to-the-non-financial-firms-divid

Samrotun, Y. (2015). Kebijakan Dividen Dan Faktor- Faktor Yang Mempengaruhinya. Jurnal Paradigma Universitas Islam Batik Surakarta, 13(01), 116095.

Sulistiyo, C. D., Hartoyo, S., \& Maulana, T. N. A. (2016). Pengaruh Rasio Keuangan Dan Perubahan Pajak Dividen Terhadap Dividend Payout Ratio Perusahaan Terbuka. Jurnal Keuangan Dan Perbankan, 20(1), 22-31. https://doi.org/10.26905/jkdp.v20i1.145

Sumampow, S., \& Murni, S. (2016). THE IMPACT OF STOCK RETURN, PRICE BOOK VALUE AND RETURN ON ASSET TO DIVIDEND PAYOUT RATIO IN BEI REGISTERED CORPORATIONS (STUDY AT TELECOMMUNCATION CORPORATION). In Pengaruh Return Saham... 795 Jurnal EMBA (Vol. 4, Issue 2).

Suwardika, I., \& Mustanda, I. (2017). Pengaruh Leverage, Ukuran Perusahaan, Pertumbuhan Perusahaan, Dan Profitabilitas Terhadap Nilai Perusahaan Pada Perusahaan Properti. None, 6(3), 254488. 